\title{
ФОРМУВАННЯ СУЧАСНОЇ ПАРАДИГМИ ПУБЛІЧНОГО УПРАВЛІННЯ В УМОВАХ ГЛОБАЛІЗАЦІЇ ТА ДЕЦЕНТРАЛІЗАЦЇ̈
}

\author{
Рагімов Ф. В., Баштанник В. В.
}

\section{ВСТУП}

Стратегічним напрямом інституціональних змін у системі державного управління в Україні $є$ трансформація наявної моделі публічної влади, запровадження принципів децентралізації, респонсивності та субсидіарності, імплементація позитивного зарубіжного досвіду організації механізмів управління на основі концепції сталого розвитку. Із метою конкретизації змісту державного управління на регіональному рівні за умов розвитку ринкових відносин важливо визначити таке: по-перше, як формується та реалізується парадигма публічного управління на національному, регіональному та субрегіональному рівні; по-друге, на основі яких принципів відбувається взаємодія механізмів управління й самоврядування; потретє, наскільки доцільним на сьогодні $\epsilon$ виокремлення субрегіональних рівнів, як забезпечити дотримання конституційних норм у процесі реформи децентралізації та яка роль органів державної влади у формуванні стратегії сталого розвитку. На основі вирішення наведених завдань можливо оцінити рівень керованості будь-яких підсистем публічного управління. Водночас якісне оновлення механізму державного управління потребуватиме врахування зовнішніх та внутрішніх факторів раціоналізації управління.

Перш за все, йдеться про гармонізацію законодавства України із законодавством $\mathrm{CC}$, імплементацію норм законодавства найбільш розвинених демократичних країн-членів СС, адаптацію національної правової системи України до європейської правової системи, проведення низки державних системних реформ (конституційної, судової, адміністративної, системи самоврядного управління, численних галузевих реформ). Водночас європейський вектор розвитку України вимагає нагального вирішення проблеми територіальної організації влади на основі побудови досконалих механізмів регіонального управління. Модернізація Української держави в умовах реалізації політики європейської інтеграції від 2014 р. визначає нові пріоритети, завдання i принципи регіонального управління, функціонування органів державної влади та місцевого самоврядування. 


\section{1. Особливості формування сучасної парадигми публічного управління в умовах децентралізації}

Актуальність дослідження особливостей формування сучасної парадигми публічного управління визначається потребою комплексного аналізу проблемних питань удосконалення регіонального на нинішньому етапі державотворення, вирішення дихотомії «централізація - децентралізація». Такий підхід грунтується на передовому зарубіжному досвіді розробки управлінських моделей, перш за все, європейської моделі багаторівневого управління. Теоретичною основою розробки сучасної парадигми публічного управління стали наукові праці вітчизняних учених, а саме: В. Бакуменка, М. Білинської, К. Ващенка, Р. Войтович, В. Голубь, О. Дація, Г. Дзяної, В. Загорського, Л. Івашової, І. Колосовської, М. Кравченко, С. Кравченка, А. Мерзляк, О. Мордвінова, 3. Надюка, Л. Новак-Каляєвої, П. Петровського, Л. Приходченко, О. Пухкала, Р. Рудніцької, Є. Романенка, С. Сороки, С. Серьогіна, О. Сушинського, В. Тертички, А. Халецької, І. Хожило, Н. Чалої, О. Федорчак, та інших. На організаційно-правових та адміністративних аспектах формування засад публічного управління акцентовано увагу у працях таких вітчизняних науковців: В. Борденюка, С. Дубенко, А. Ліпенцева, С. Матвіїшина, О. Петришина, Н. Плахотнюк, В. Цвєткова, В. Шаповала, Ю. Шемшученка тощо. Аналіз теоретичних і прикладних аспектів впливу сучасних процесів глобалізації та децентралізації на формування концептуальних засад управління в зарубіжних країнах здійснено в дослідженнях таких зарубіжних учених, як Г. Алмонд, З. Бжезинський, Д. Белл, П. Бергер, Е. Гідденс, С. Ліпсет, Д. Медоуз, А. Печчеі, Д. Стігліц, А. Тойнбі, О. Тоффлер, Ф. Фукуяма, Ю. Хабермас, С. Хангтінгтон, Ф. Хаєк, Д. Шуман.

Інституціональне та організаційно-правове забезпечення формування сучасної парадигми публічного управління в межах окремих досліджень спеціально не вивчалось. У наукових працях ці питання досліджено в контексті проблематики становлення та розвитку механізмів діяльності органів виконавчої влади та місцевого самоврядування, секторальної децентралізації влади, а також аспектів реформування публічного управління. Водночас публічне управління в більшості досліджень $є$ усталеним поняттям, що апріорно визначається на основі положень міжнародних правових актів, доктрин, концепцій, які вказують на інтегрування проблем публічних послуг, повноважень, відповідальності тощо.

Власне, необхідність застосування нових підходів та інструментів до формування парадигми публічного управління актуалізувало аналіз i застосування принципово нової методології дослідження, котра базується на узагальненні науково-практичного досвіду нормативно- 
правового забезпечення функціонування системи публічного управління, систематизації організаційних засад державної політики. Вибір методів дослідження зумовлений метою та завданнями публічного управління, водночас особливий акцент варто зробити на таких напрямах:

- теоретико-методологічне узагальнення досліджень засад регулювання діяльності органів влади;

- аналіз та синтез ефективних напрямів регулювання розвитку національної держави у кризовий період,

- порівняльний аналіз зарубіжного досвіду організації публічного управління в контексті можливості його застосування в Україні;

- функціональний аналіз для обгрунтування напрямів удосконалення публічного управління та розроблення структурнофункціональної моделі механізму управління для обгрунтування підходів до гармонізації загальнодержавних, регіональних і місцевих інтересів та засад правового регулювання в забезпеченні розвитку сучасної держави.

Сучасна методологія дослідження основ формування парадигми публічного управління передбачає застосування порівняльного аналізу діяльності органів влади в Україні та зарубіжних країнах. Такий аналіз базується на принципах інноваційності: поєднання конституційно встановлених процедур державного адміністрування та складників соціального управління; розвиток демократичних принципів державного регулювання, інституціоналізація громадського впливу на прийняття державно-управлінських рішень у процесі вироблення державної політики; об'єктивність, загальнодоступність, повнота й оперативність інформації; раціональна організація апарату управління; планування та прогнозування розвитку; проведення кадрової політики в органах державного управління за принципами професіоналізму; гарантія законності та контроль за виконанням і дотриманням законів.

Аналіз діяльності органів влади в Україні у 1991-2019 рр. дозволяє чітко визначити особливості трансформації формування владного механізму, розглянути причини неефективних дій структур управління. Водночас у дослідженнях проблем формування парадигми публічного управління доцільно оперувати визначенням системи як цілісного утворення 3 новими інтегративними якостями, що не властиві його компонентам окремо, а виникають завдяки їх взаємодії. Адже власна національна система публічного управління в Україні визначається через дотримання певних правил i процедур саме демократичного врядування, що формалізовані у процесі європейської інтеграції, й уточнюються в контексті поняття «європейська ідентичність» як у правових актах $\mathrm{CC}$, так і у двосторонньому форматі «Україна - СС». 
Насправді взаємодія в певній системі управління визначається потребами саморегуляції, збереження й саморозвитку управлінських систем різного рівня складності, виявляється у процесах управління, у зміні систем, у поєднанні з інформацією про об'єкт і мету управління.

Саме тому науковим завданням дослідження концептуальних засад публічного управління $є$ побудова ефективної інтегрованої системи управління відповідно до європейських традицій належного врядування й одночасно - формулювання сучасної національної ідеї Української держави - «Україна - європейська держава». Водночас дослідження європейського досвіду конституювання систем публічного управління дозволяє запропонувати інтегровану систему публічного управління в контексті розвитку євроінтеграційного процесу.

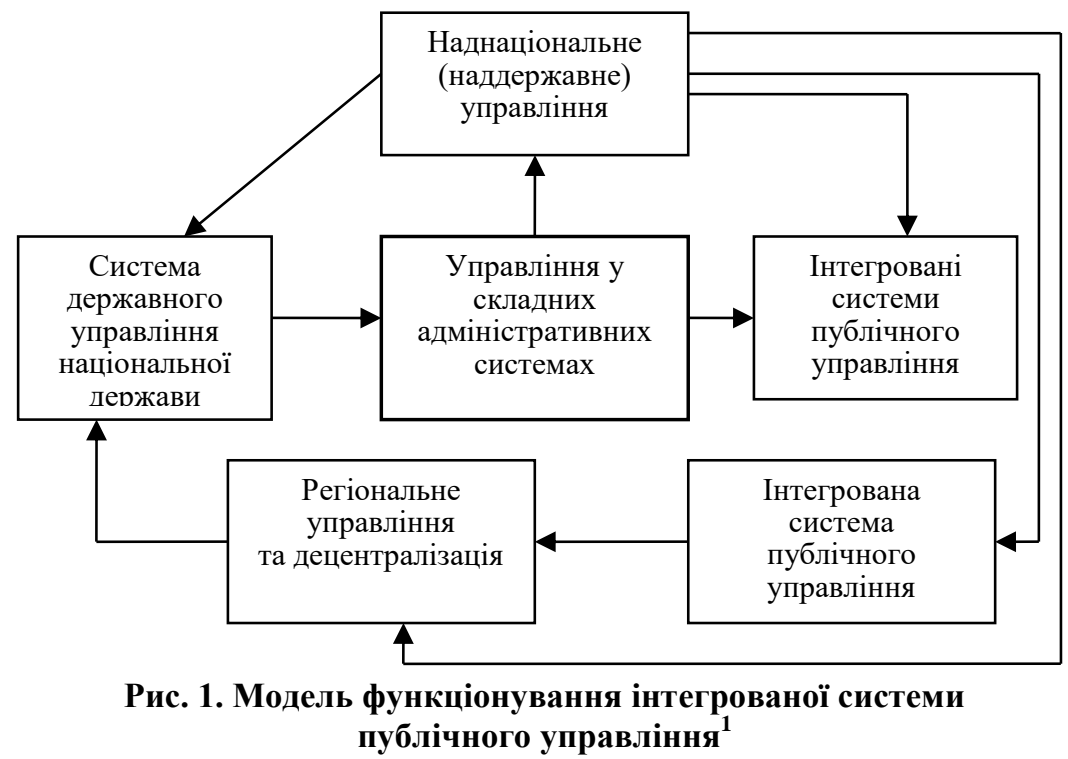

Загалом, публічне управління в Україні виступає у сучасних умовах як цілеспрямований організуючий та регулюючий вплив держави (через систему органів влади та посадових осіб) на суспільні процеси й діяльність людей із метою реалізації суспільної потреби в управлінні відносинами в системі «державна влада - суспільство особистість». Реформування всієї сфери публічного управління має

\footnotetext{
${ }^{1}$ Баштанник В. Трансформація державного управління в контексті європейських інтеграційних процесів. Дніпропетровськ, 2010. 390 с.
} 
базуватись на демократизації управлінських відносин, відповідно до принципів розподілу влади, відкритості, підконтрольності суспільству, за умови суспільної взаємодії як результату узгодження інтересів соціальних груп.

Водночас у контексті детермінації парадигми публічного управління на рівні національної держави зазначимо, що нині відбувається процес виокремлення самостійних чинників впливу на трансформацію управління, через, по-перше,дотримання комплексу «зовнішніх критеріїв» (стандарти $\mathrm{CC}$, особливості відносин із міжнародними організаціями); по-друге, абсолютизацією політичного чинника в державному управлінні (наприклад, своєрідне «квотування» посад у державному управлінні через інститут політичних, адміністративних та патронатних посад). Сучасна трансформація державного управління в умовах децентралізації на цьому історичному етапі не мінімізує кризові ситуації в системі публічного управління, а створює самостійні колізії в управлінському механізмі держави. Власне, у 2005-2019 рр. трансформаційний процес почав самостійно провокувати нові кризи суспільного управління, котрі негативно вплинули на механізм формування парадигми публічного управління.

Вважаємо обгрунтованим сучасний підхід вітчизняних дослідників щодо теоретико-методологічної проблеми публічного управління, яка зводиться до того, що «процеси управління властиві лише складним, динамічним системам, іманентним атрибутом яких $є$ самоуправління, тобто здатність до впорядкування системи, приведення iї у відповідність до об'єктивної закономірності певного середовища,

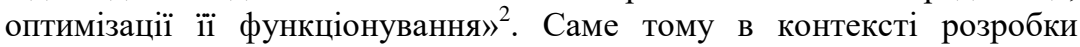
парадигми публічного управління важливо вказати, що управління як соціальне явище на сьогодні детермінується потребами суспільного розвитку та потребує регулювання діяльності органів державної влади шляхом правового визначення форм, методів, принципів такого регулювання. Необхідно вказати на дискусійність сучасного трансформаційного тренду у сфері публічного управління, зумовленого інституціональною зміною системи управління, дихотомією конституційних норм і положень законопроєктів у сфері державного та регіонального управління, нерозробленістю функціональних механізмів управління. Актуальність вирішення проблеми раціональності управління полягає в теоретико-методологічному обгрунтуванні категорій «механізми державного управління», «соціальна держава», «публічне управління», а також у виявленні взаємозалежності процесів

${ }^{2}$ Вахович В. Концептуальні засади дослідження сталого розвитку суспільства. URL: http://wp.viem.edu.ua/konfu/art.php?id=0105. C 40 (дата звернення 03.06.2020). 
децентралізації, глобалізації, інтеграції, ствердженні в управлінні концепції сталого розвитку (рис. 2).

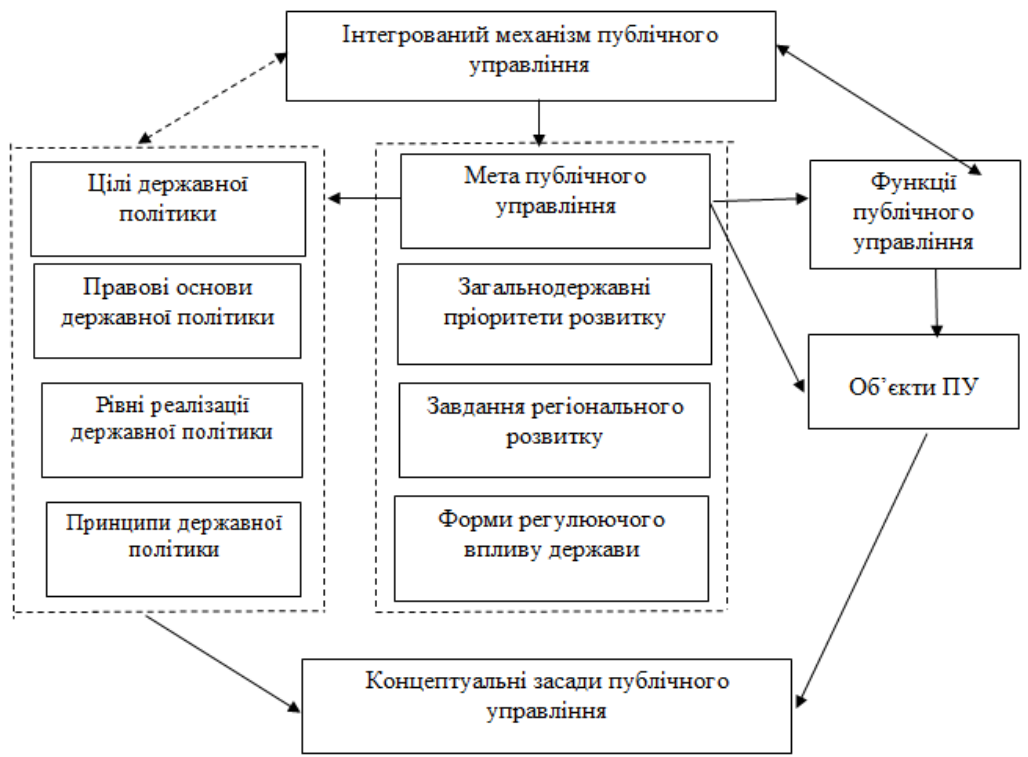

\section{Рис. 2. Схема формалізації основ формування парадигми публічного управління}

Система державного управління в України перебуває на етапі радикального реформування, модернізації принципів, правил i процедур. Це передбачає зміни в діяльності органів публічної адміністрації, до якої за європейською традицією ми відносимо органи виконавчої влади та органи місцевого самоврядування, імплементацію сучасних європейських принципів управління. Свропейські принципи публічного управління як сучасні загальновизнані демократичні цінності європейської цивілізації слугують орієнтиром проведення державно-правових реформ у країнах Центральної та Східної Свропи.

Побудова демократичної, правової держави потребує чіткого наукового уявлення про ознаки, особливості, властивості, характерні риси управління, котрі притаманні всім суспільствам на різних стадіях розвитку. Водночас надзвичайно важливе розуміння характеру державного (в широкому розумінні - публічного) управління, здійснюваного в конкретних просторових межах. Адже процес управління повинен якомога повніше відповідати демократичним принципам, позаяк люди володіють невід'ємним, природним правом на 
самоврядування ${ }^{3}$. Базова теоретико-методологічна проблема управління зводиться до того, що процеси управління властиві лише складним, динамічним системам, іманентним атрибутом яких $\epsilon$ самоуправління, тобто здатність до впорядкування системи, приведення іiі у відповідність до об'єктивної закономірності певного середовища, до оптимізації її функціонування.

Управлінська наука розглядає суспільство як цілісну, складну, динамічну, самокеровану систему, розвиток якої підпорядкований об’єктивним законам. Суспільство - найвищий тип соціальної організації - існує тільки тоді, коли саме функціонує як складне цілісне утворення. Таким системам властиві різноманітні процеси управління. Із цим пов'язана i друга проблема - співвідношення стихійного i свідомого, об'єктивного і суб'єктивного в регулюванні суспільного життя. Об'єктивні закони функціонування й розвитку суспільства діють за посередництва всіх видів регулювання. Управління - це свідоме регулювання суспільних відносин, а за джерелом дії воно є зовнішнім щодо процесу самоуправління. Однак це не означає, що на зазначеній та попередніх стадіях розвитку суспільства людина не справляла свідомого цілеспрямованого впливу на чинну систему ${ }^{4,5}$. Адже питання про ступінь керованості суспільним життям значною мірою залежить від взаємодії соціальних інтересів, оскільки існування й розвиток суспільства - не що інше, як діяльність людини, соціальних груп, пов'язана з реалізацією своєї мети.

\section{2. Завдання й функції держави, стратегії її розвитку}

\section{як чинники формування парадигми публічного управління}

Повноцінна демократія неможлива й нездійсненна без інтегрування людини у владні відносини. Тому наступним кроком України має бути зміцнення влади громад - місцевого самоврядування. Будь-які заходи, котрі плануються в межах адміністративно-територіальної реформи, спрямовуватимуться виключно на те, щоб кожна людина в місті чи селі могла вчасно, повно і якісно реалізувати свої природні й конституційні права. Тому майбутнє України - в організованій, потужній та

Виникнення та аналіз поняття «Сталий розвиток». Економіка. Вісник Дніпропетровської державної фінансової академії. URL: http://www.stattionline.org.ua/ ekonom/57/7726-viniknennya-ta-analiz-ponyattya-stalij-rozvitok.html. C. 68-70 (дата звернення 03.06.2020).

${ }^{4}$ Воротін В. Макроекономічне регулювання в умовах глобальних трансформацій. Київ, 2002. С. 112.

5 Гавриш О., Бичков О. Інституціональні аспекти забезпечення стійкого розвитку підприємств. URL: http://www.economy.nayka.com.ua/?op=1\&z=1060 (дата звернення03.06.2020). 
спроможній громаді. Державна влада може й має співіснувати із владою громади - на основі чіткого розподілу повноважень i відповідальності та завдяки тісній взаємодії і взаємодоповненню. Жодна 3 функцій на будь-якому рівні не повинна дублюватись. Децентралізація влади буде ефективною лише за умови, якщо відбуватиметься одночасно у двох напрямах: від держави - громаді та від центральних органів влади - органам державної влади на місцях. У такому форматі відносин децентралізація як принцип (концепт) публічного управління має забезпечити наближення влади, владних механізмів і функцій до людей, а не зводитись до укрупнення районів, картографічного об’єднання населених пунктів, закриття шкіл та бібліотек.

Свропейський досвід у контексті його впровадження для підвищення ефективності державного управління, створення умов взаємодії суб'єктів політичного й соціального процесу необхідний, перш за все, для усвідомлення позитивних i негативних проявів суспільних відносин; для побудови моделі функціонування органів влади, створення раціонально структурованого владного механізму країни. Аналіз та узагальнення досвіду (зарубіжного, історичного тощо) функціонування системи органів влади особливо важливий в умовах перехідного періоду, коли об'єктивно $є$ потреба в сильній виконавчий владі, політично вольовому Президентові, за наявності мажоритарної чи змішаної виборчої системи.

Досить довго у вітчизняній науці домінувала недооцінка зарубіжного досвіду через ідеологічні чинники. Нині зовнішня i внутрішня політична ситуація актуалізують посилену увагу до вивчення та впровадження досвіду країн Європи, зокрема Європейського Союзу (ЄС). У контексті реформування державного управління в Україні напрямами відповідних грунтовних наукових досліджень мають виступати європейські концепції державного управління. Наявні процеси в Європейському Союзі свідчать про трансформацію держави в регіональному форматі, яка розвивається через дві концептуальні моделі: «Свропа регіонів» та «Свропа через регіони». Це не стосується радикальних форм регіоналізму, що мають істотний дезінтеграційний потенціал і можуть слугувати суттєвим чинником нестабільності та загрожувати територіальній цілісності національної держави.

Отже, концепт «Свропа регіонів» може виступити фундаментом формування сучасної парадигми публічного управління, оскільки обгрунтовує можливість через інтеграційні процеси змінити баланс сил на континенті й надати регіонам можливість стати автономними суб’єктами. Модель «Європа через регіони» синтезує в собі позитив 
різних форм регіоналізму, вдосконалює і пристосовує їх до сучасних реалій, оскільки побудована на ідеях утвердження регіону як повноцінного та рівноправного партнера у структурі $\mathrm{EC}$, щоб забезпечити інституційний плюралізм ${ }^{6}$. У такому сенсі національна парадигма публічного управління в Україні має формалізувати основи регіоналізму як засадничого концепту зазначеної парадигми.

Принагідно варто наголосити на принципах реформування державного управління у країнах Західної Європи, зокрема, на принципі демократизації (відкритість, інформованість, комунікабельність), принципі орієнтації на клієнта, принципі орієнтації на кінцевий результат, принципі рентабельності, принципі простоти управління (підвищення оперативності, спрощення управлінських структур). Досягнення конкретних результатів управління за умов реалізації таких принципів можливе лише за умов чіткої взаємодії органів влади всіх рівнів із політичними партіями, котрі представляють різноманітні суспільні групи. Окрім того, політична та адміністративна реформи, які проводяться в Україні із середини 90-х рp. XX століття із незначними перервами, не вирішили проблему адаптації бюрократії до демократичних перетворень, що знайшло свій прояв у відсутності комплексу стратегічних національних пріоритетів, заявлених інститутами влади в Україні. Варто погодитись із тезою, що саме право ЄC і співпраця в управлінській сфері все більше впливають на діяльність адміністративних, організаційних, правових і політичних структур національних держав. Європейське врядування (в нашому контексті - європейську інтегровану систему публічного управління, діяльність структур якого реалізована як модель механізму делегованих повноважень) необхідно розглядати. Саме тому питання суспільнополітичного розвитку кожної країни базуються на визначенні напрямів державної політики в системі зовнішньо- та внутрішньополітичних пріоритетів.

У зарубіжних та вітчизняних наукових дослідженнях галузей адміністративного права, політології, філософії та державного управління започатковані й успішно реалізовані самостійні напрями досліджень окремих питань демократизації управління, формування організаційно-правових засад управлінської діяльності, впливу зовнішнього середовища на суспільне управління, проблематики інститутів представницької демократії. Водночас поза увагою залишаються питання формування інтегрованих систем управління

${ }^{6}$ Баштанник В. Концептуальні засади реформування державного управління в умовах сучасного етапу розширення СС. Наук. вісн. Акад. муніи. упр. 2011. № 3. C. $78-86$. 
(перш за все, публічного), місця й ролі суспільних інститутів та реалізації принципу ієрархії в таких системах. У сучасних умовах в Україні актуалізується напрацювання засад конституювання інтегрованих систем публічного управління, що передбачає на першому етапі розробку методології дослідження наявних управлінських систем на рівні національних держав Європи, систематизацію принципів діяльності в таких системах, визначення особливостей прямих та зворотних зв'язків у таких системах та відносини з надсистемами в сенсі глобалізації управління тощо.

Дихотомія сучасного управління суспільним розвитком пов'язана 3 політичною сутністю держави як інституту влади i, водночас, iз раціоналізацією владних відносин, динамікою політичних процесів, політичними трансформаціями, зокрема й під впливом зовнішніх чинників. Водночас особливу увагу варто приділяти визначенню ієрархії проявів суто організаційного характеру. Адже організація влади в державі вимагає формування інститутів управління, котрі поєднують політичну владу й адміністрування (в сучасних умовах частково забезпечується інститутом політичних посад та специфікою формування представницьких органів).

Сучасна правова база формування парадигми публічного управління засвідчує суто політичний характер функціонування державної влади (яку зараз намагаються квазідецентралізувати, що дає підстави стверджувати факт зрощування адміністрування й політичного управління в Україні. Утім, якщо зважати на функціональні характеристики, публічне адміністрування необхідно визнати самостійним рівнем управління, в межах якого поєднуються оперативне й тактичне управління, а також виокремлюється демократичний характер публічного управління. Формування базових засад державноуправлінської діяльності в Україні в умовах трансформації наднаціональних, національних, регіональних та самоврядних структур управління виступає важливим складником процесу демократизації суспільних відносин, імплементації європейських принципів взаємодії органів влади різних рівнів, інтеграції концептуальних засад організації й розподілу владних повноважень.

Зростання ефективності державно-управлінської діяльності в Україні можливе через удосконалення форм, методів та механізмів діяльності органів публічної влади на підставі адаптації вітчизняної теорії управління розвитком адміністративно-територіальних утворень, відповідно до принципів регіональної політики СС та запровадження на національному грунті загальноєвропейських традицій урядування в контексті тези «Від «Свропи держав» - до «Європи регіонів»». Так, систему публічної адміністрації розглядають як: 
- сукупність державних і недержавних суб’єктів публічної влади, ключовими структурними елементами котрої $\epsilon$, по-перше, органи виконавчої влади i, по-друге, виконавчі органи місцевого самоврядування);

- апарат управління публічними справами, який займається реалізацією цілей, визначених політичною владою;

- організація, що здійснює будь-яку державну діяльність і яка не знаходиться під керівництвом ні законодавчої, ні судової влади;

- планована людська діяльність, спрямована на досягнення певних суспільних цілей;

- процес досягнення національних цілей за допомогою публічних організацій;

- організація та діяльність органів й установ, підпорядкованих політичній владі, котрі забезпечують виконання закону, діють у публічних інтересах і наділені прерогативами публічної влади.

У контексті розвитку сучасного світу важлива роль належить регіональним суб'єктам управління, адже сьогодні саме регіони, а не національні держави, $є$ головними політичними суб'єктами формування нової системи публічного управління. Сьогодні йдеться про нову конфігурацію світового устрою, в межах якої національна держава в іiі традиційному розумінні втрачає своє функціональне призначення, а на зміну їй приходять нові «квазідержавні структури», що визначають розвиток сучасного світу. Однією 3 форм функціонування таких структур є регіоналізація, котра набирає таких обертів, що фактично являє собою обернену форму глобалізації 7 .

Регіоналізація як нова альтернативна модель світу формує нові інституційні структури його розвитку, котрі не займають чітко встановлених територій, проте диктують свою систему критеріїв вимог до мешканців цієї території. Водночас такий вияв регіоналізації завжди базується на концепції сталого розвитку як «ідеологічної» платформи впровадження принципів децентралізації. Загалом, характер регіоналізації залежить від суб'єктів іiї здійснення. Суб'єктами сучасної регіоналізації виступають країни, котрі беруть на себе функції 3 формування територіальної системи міжнародних відносин. Таким чином, активними суб'єктами регіоналізації стають держави-лідери геополітичного простору, котрі вдаються до створення відповідних регіональних об'єднань лише 3 однією метою - реалізувати власні

${ }^{7}$ Рагімов Ф., Гацуля О. Удосконалення організаційно-правового забезпечення державного управління на регіональному та галузевому рівнях у контексті процесів децентралізації Державне управління та місиеве самоврядування : зб. наук. пр. Днеіпропетровськ. 2015. Вип. 3. С. 101-112. 
геополітичні амбіції, які б забезпечили національній державі статус наддержави ${ }^{8}$.

Загалом, на підставі аналізу європейського досвіду формування та реалізації євроінтеграційної політики на національному та регіональному рівні нами пропонується до застосування модель адаптації євроінтеграційного досвіду країн СС в Україні як поєднання таких складників: комплекс концептуальних, методологічних і практичних вимог до формування і впровадження інтеграційної політики; комплекс напрямів гармонізації вертикальних інституціональних зв'язків між центральним (національним) і регіональним рівнями під час реалізації євроінтеграційної політики; комплекс напрямів поліпшення горизонтальної координації органів влади й управління (як на центральному, так i на регіональному рівнях) у визначенні i впровадженні євроінтеграційної політики; система заходів щодо вибору прийнятної моделі регіональної політики, ії фінансових та економічних механізмів, а також правової бази, що сприятимуть зменшенню регіональної асиметрії в Україні.

Водночас проявляються й такі чинники дезінтеграційних процесів:

- глибинні кризові явища в економіці після розпаду СРСР, які й зараз даються взнаки;

- розрив сформованих зв'язків споживачів i постачальників, пріоритетна орієнтація виробництва на зовнішній ринок;

- відсутність, зокрема, небажання відмовлятись від ручного управління регіонами;

- регіоналізація суспільного життя, поява «самодостатніх» регіонів, прагнення регіональних лідерів до надмірної політичної та економічної самостійності;

- надмірна політизація економіки та відсутність достовірної оперативної інформації;

- недосконалість міжбюджетних відносин тощо.

Суспільно-політичні перетворення в Україні, основою яких виступили кардинальні зміни політичного режиму 2004-2019 pp. формування демократичних засад державного управління, європейський стиль політичного керівництва, - визначили європейську спрямованість національного розвитку, прагматизм зовнішньої політики України, фундаментальні зрушення в національній свідомості. Цілком правомірно варто зазначити, що одночасно 3 початком державотворчих процесів інтеграція до європейських політичних,

8 Рагімов Ф. Теоретико-методологічні засади механізмів регіонального управління в умовах глобалізації. Наук. вісн. Акад. муніціп. упр. Зб. наук. пр. сер. Управління. 2016. № 4. С. 111-115. 
економічних структур та структур безпеки стала головним зовнішньополітичним пріоритетом нашої держави. Адже європейська інтеграція є процесом, котрий не має визначеного закінчення, оскільки, з одного боку, ЄС постійно розширюється, а з іншого - європейська інтеграція поглиблюється: країни-члени з часом делегують ЄС частину своїх повноважень. Природно, важко визначити, як інституціалізується ЄC у найближчі роки. Так само достеменно незрозуміло, які повноваження національного рівня управління будуть збережені на рівні держав, а які - делегують до структур управління. У такому форматі напрацювати сучасну парадигму публічного управління достатньо складно. Саме тому штучне, необгрунтоване проведення реформи децентралізації здатне зруйнувати модель публічного управління, призвести до декомпозиції державних інституцій.

Україні важливо використати досвід регіонального управління країн-членів СС, де було знайдено досконалий алгоритм подолання економічних протиріч та проблем. Регіональна політика Європейського Союзу базується на таких принципах:

- принцип концентрації вимірів регіональної політики СС навколо пріоритетних регіональних напрямів окремих держав-членів ЄС (зважаючи на значні розбіжності розвитку європейських регіонів);

- принцип партнерства: максимальне зближення можливостей Європейської Комісії та органів влади на національному, регіональному та місцевому рівнях у процесі підготовки та впровадження рішень;

- принцип програмування: кожна програма на конкретному рівні прийняття рішень максимально узгоджена 3 іншими окремими програмами;

- принцип комплексності: передбачає фінансування 3 фондів ЄС завжди разом із витратами національних урядів.

Пропозиції щодо нової парадигми публічного управління мають ураховувати зміни, котрі відбулись та відбуваються в Україні у сфері державного регулювання територіального розвитку, формування інституційних засад регіональної політики, впорядкування відносин центру й регіонів тощо. Аналіз процесів регіонального розвитку України свідчить про наявність негативних тенденцій, зокрема поглиблення міжрегіональних суперечностей, зростання диспропорцій та загострення економічних і соціальних проблем регіонів. Головною причиною розвитку цих тенденцій є відсутність цілісної дієвої системи реалізації державної регіональної політики, ефективного механізму відносин центру 3 регіонами та регіонів між собою. Несистемним залишається правове поле у сфері регулювання регіонального розвитку. 
Поряд із класичними інтеграційними концептами в сучасних умовах посилення інтеграційних тенденцій, інтернаціоналізації виробництва та глобалізації людського розвитку українські реалії детермінували вагомим складником політики національної держави:

- намагання надати принципово нового трактування категорії «національний суверенітет»;

- запропонувати сучасну концепцію делегованого управління як надання права прийняття управлінських рішень, віднесених до компетенції наддержавних (наднаціональних) утворень;

- напрацювати ефективні механізми регіонального та глобального співробітництва.

Зрозуміло, що в такому форматі змінюються всі складники національних політико-правових систем: система державного управління, система місцевого самоврядування, система політичних партій та громадських організацій. Очевидно, що будь-яка трансформація зазначених політичних суб'єктів потребує попередньої сталості та системності, оскільки в іншому разі виникає загроза деформації не лише на рівні принципів, мети, суспільних ресурсів влади, а й ефективної стратегії розвитку суспільства.

Головна мета перетворень системи територіальної організації влади може бути вирішена лише у форматі нової парадигми публічного управління - побудови децентралізованої моделі організації державної влади, яка могла б в умовах ринкової економіки результативно та ефективно впливати на процеси соціально-економічного й культурного розвитку територій, забезпечувала б якісний рівень надання управлінських послуг населенню на рівні європейських стандартів, була б здатна до самовдосконалення й саморегуляції. На нашу думку, вирішення проблем розвитку регіонального управління вбачається шляхом: по-перше, раціоналізації адміністративно-правового регулювання через здійснення адміністративної реформи на місцевому та регіональному рівнях організації влади, розмежування функцій i повноважень між місцевими органами виконавчої влади та органами місцевого самоврядування, а також між органами місцевого самоврядування різних рівнів; розв'язання проблем стратегічного планування розвитку територій, налагодження міжсекторного співробітництва місцевих органів влади, неурядових організацій, бізнесових структур; удосконалення статусу органів місцевого самоврядування регіонального рівня, місцевих державних адміністрацій. По-друге, вдосконалення конституційно-правових гарантів розвитку самоврядних структур через законодавче забезпечення розвитку (реформи) місцевого самоврядування - прийняття Закону «Про регіональне управління та територіальну організацію влади в Україні»; 
розробку і прийняття Програми законодавчого забезпечення розвитку регіонального управління; здійснення кодифікації законодавства про територіальне управління.

По-третє, реформування політики розвитку самоврядних структур через пропозиції щодо зміцнення фінансових основ місцевого самоврядування та вдосконалення положень Бюджетного кодексу України в частині «формульного підходу», міжбюджетних відносин на рівні ОМС; розробка державних соціальних стандартів надання громадських послуг населенню та фінансових нормативів їх забезпечення; проведення паспортизації комунальних бюджетних установ та об'єктів, визначення фактичних витрат на їх утримання.

По-четверте, вирішення питань системного розвитку адміністративно-територіальних одиниць через здійснення реформи адміністративно-територіального устрою, вдосконалення системи адміністративно-територіального устрою, визначення статусу адміністративно-територіальних одиниць первинного рівня та критеріїв забезпечення їх дієздатності та самоврядності; визначення кордонів адміністративно-територіальних одиниць; проведення комплексу земельних кадастрових робіт; розробка і прийняття Закону України «Про порядок вирішення питань адміністративно-територіального устрою». Потребують вирішення інші питання місцевого та регіонального розвитку, зокрема такі: державна підтримка депресивних територій та територій пріоритетного розвитку; вдосконалення законодавства про місцеві вибори на основі змішаної мажоритарнопропорційної системи; зміцнення транскордонного і прикордонного співробітництва, зокрема, у зв'язку з розширенням Європейського Союзу; розв'язання проблем наукового, освітнього, інформаційного забезпечення розвитку місцевого самоврядування; вдосконалення кадрового забезпечення регіонального управління.

Кінцевою метою вдосконалення організації влади на регіональному й локальному рівнях має стати розбудова сучасної європейської комунальної (муніципальної) моделі місцевого самоврядування, визначення структури адміністративно-територіального поділу України. Здійснення адміністративної реформи на місцевому рівні на визначених концептуальних засадах приведе до підвищення рівня життя громадян, дотримання гарантованих соціальних стандартів, створення умов для отримання громадянами України сучасних управлінських (адміністративних) послуг.

Проблеми відповідальності за виконання стратегій регіонального розвитку можна звести до основної - відсутності унормованої державної регіональної політики, яка за своєю суттю стала б інноваційною парадигмою (теоретико-методологічним підгрунтям 
сталого регіонального розвитку, оскільки містила б ефективні інструменти для вирішення проблем асиметрії розвитку регіонів України з урахуванням специфіки їх економіки, екології, демографії, освіти, світоглядних орієнтацій населення. Метою такої політики має стати забезпечення нової якості життя людини. Вирішення цієї проблеми зумовлює необхідність задоволення низки потреб у практичній правотворчій площині. Так, першою потребою на шляху до правового забезпечення інноваційної парадигми публічного управління $€$ вдосконалення конституційної моделі територіальної організації влади в частині адміністративно-територіального устрою та місцевого самоврядування, відповідно до засад децентралізації державної влади.

\section{ВИСНОВКИ}

Варто зазначити, що публічне управління інтегрує соціальне управління, регулювання суспільних відносин та організацію державної влади. Системний вплив держави на суспільні відносини більшість науковців розглядає як поєднання двох складників - політичного управління та адміністрування. У такому прояві спостерігаємо дихотомію сучасного управління суспільним розвитком, що пов'язано 3 політичною сутністю держави як інституту влади i, водночас, iз раціоналізацією владних відносин, динамікою політичних процесів, політичними трансформаціями, зокрема й під впливом зовнішніх чинників. Саме тому політичний аспект влади детермінує державну владу як реальну спроможність суспільного суб'єкта проводити свою волю в державній політиці та правових нормах, наголошуючи на інтегративній ролі державної влади в суспільстві та ролі державних структур у процесі становлення громадянського суспільства.

Сучасну систему демократичного врядування цілком умотивовано варто детермінувати як інструмент забезпечення існування держави, досягнення іï цілей. Водночас публічна влада й, загалом, система публічного управління на рівні національної держави здатна впливати на суспільні процеси, поведінку окремих соціальних груп за допомогою спеціальних органів й установ як складників єдиного механізму влади. Визначення системи управління як організованого, регулюючого та інтегрованого впливу на суспільну та групову життєдіяльність, що здійснюється безпосередньо чи опосередковано - через державу, самоврядні структури, партії - дозволяє детермінувати публічне управління як цілеспрямований, організаційний, системний вплив політичної влади на життєдіяльність суспільства. Визначальним суб'єктом такого управління в межах суспільних відносин уважаємо орган публічної влади - складник державного апарату, групу осіб чи особу, наділені законодавчо встановленими владними повноваженнями 
для виконання завдань i функцій управління. Механізми взаємодії суспільства і влади у процесі прийняття рішень нині не публічні та досить хаотичні, канали впливу на органи державної влади монополізовані наймогутнішими групами тиску, велика кількість громадських рухів та організацій не можуть донести свої інтереси до влади.

Iз позицій європейського інституціоналізму важливо охарактеризувати складники розробки та запровадження парадигми публічного управління, що визначає зміст децентралізації державної влади. Ця парадигма базується на таких складниках: по-перше, порядок формування цілей та завдань розвитку публічного управління в системному поєднанні 3 національними інтересами; функції й компетенцію органів державного управління, їх посадових осіб як суб'єктів формування державної політики; правовий статус органів державного управління та місцевого самоврядування; предмет управлінського впливу, відносини з іншими органами державної влади. По-друге, організаційно-правові форми та методи діяльності органів державної влади й місцевого самоврядування; принципи організації та функціонування органів влади; структуру та характер відносин елементів системи органів влади. По-третє, правовий статус посадових осіб; мета, основні напрями та організаційні основи функціонування об'єктів організаційно-управлінського впливу.

\section{АНОТАЦІЯ}

Досліджено особливості й тенденції функціонування механізмів державного управління розвитком регіонів в умовах децентралізації. Обгрунтовано зміст сучасного концепту публічного управління, доведено дихотомічний зв'язок процесів регіоналізації, глобалізації та децентралізації. Проаналізовано проблемні питання формування сучасних механізмів регіонального розвитку. Запропоновано організаційні заходи щодо раціоналізації функціонування механізмів державного управління сталим розвитком регіонів. Визначені особливості формування основ регіонального управління з урахуванням європейських трендів регіоналізації. Установлені напрями раціоналізації регіональних механізмів управління в контексті сталого розвитку як сучасної парадигми системних реформ. Доведено, що за основними ознаками (джерелом влади, характером взаємодії суб'єкта й об'єкта управління, природою соціальних норм) у межах децентралізованої системи інститут самоврядування співвідноситься 3 державним управлінням як складники публічного управління. Проведено оцінку ефективності децентралізації в контексті можливості реалізовувати державну політику реформ. 


\section{ЛІТЕРАТУРА}

1. Баштанник В. Трансформація державного управління в контексті європейських інтеграційних процесів. Дніпропетровськ, 2010. 390 с.

2. Вахович В. Концептуальні засади дослідження сталого розвитку суспільства. URL: http://wp.viem.edu.ua/konfu/art.php?id=0105. С 40 (дата звернення 03.06.2020).

3. Виникнення та аналіз поняття «Сталий розвиток». Економіка. Вісник Дніпропетровської державної фінансової академії. URL: http://www.stattionline.org.ua/ekonom/57/7726-viniknennya-ta-analizponyattya-stalij-rozvitok.html. C. 68-70 (дата звернення 03.06.2020).

4. Воротін В. Макроекономічне регулювання в умовах глобальних трансформацій. Київ, 2002. с. 112

5. Гавриш О., Бичков О. Інституціональні аспекти забезпечення стійкого розвитку підприємств. URL: http://www.economy. nayka.com.ua/ ?op=1\&z=1060 (дата звернення 03.06.2020).

6. Баштанник В. Концептуальні засади реформування державного управління в умовах сучасного етапу розширення СС. Наук. вісн. Акад. муніи. упр. 2011. № 3. С. 78-86.

7. Рагімов Ф., Гацуля О. Удосконалення організаційно-правового забезпечення державного управління на регіональному та галузевому рівнях у контексті процесів децентралізації Державне управління та місиеве самоврядування : зб. наук. пр. Днеіпропетровськ. 2015. Вип. 3. C. 101-112.

8. Рагімов Ф. Теоретико-методологічні засади механізмів регіонального управління в умовах глобалізації. Наук. вісн. Акад. муніціп. упр. 3б. наук. пр. сер. Управління. 2016. № 4. С. 111-115.

\section{Information about author:} Ragimov F. V.,

Candidate of Science in Public Administration, Doctoral Student of the Dnipropetrovsk Regional Institute for Public Administration of the National Academy for Public Administration under the President of Ukraine 29, Hoholia Str., Dnipro, 49600, Ukraine ORCID: 0000-0001-5645-4560

\section{Bashtannyk V. V.,}

Doctor of Science in Public Administration, Professor, Dnipropetrovsk Regional Institute for Public Administration

of the National Academy for Public Administration under the President of Ukraine 29, Hoholia Str., Dnipro, 49600, Ukraine ORCID 0000-0001-5969-3620 